\title{
Empowering students to take ownership of their learning: Lessons from one piano teacher's experiences with transformative pedagogy
}

As the number of adults seeking to learn the piano increases, so too does the need for piano teachers to understand how to better facilitate their learning. Self-direction is an oft-cited requirement of adult learning, but one that is often absent from piano studios. This practitioner-based research investigates the role of the teacher in fostering and supporting self-direction, empowering adult piano students to take ownership of their learning. It offers pedagogical insights into the author's experiences within her own piano studio and details the practical application of theories and strategies offered within the fields of piano pedagogy and adult learning.

This study finds that fostering self-direction is more complex than offering the balance between guidance and freedom that some experts suggest. It also requires strong student-teacher rapport, supporting and building students' selfefficacy and being willing to set aside expectations. This was made possible by implementing transformative pedagogical strategies, such as effective questioning, collaborative discussions and adapting the structure of lessons. While the author's journey is uniquely her own, the approaches used to engage adult students with their learning, and the use of reflective practice as professional development, may be of interest to other studio instrumental teachers.

Keywords: adult piano student, piano pedagogy, practitioner-based research, reflective practice, self-direction, transformative pedagogy

As the number of adults seeking to learn the piano increases, so too does the need for piano teachers to understand how to better facilitate their learning. Adult students often have a desire for immediate perfection, rather than the time and repetition required to learn, and feel frustrated at motor-cognitive disconnect, whereby procedural memory occurs slower than cognitive understanding (Cooper, 2001; Maris, 2000; A. Taylor, 2011; Uszler \& Upitis, 2000; Wristen, 2006). This can lead to the use of ineffective practice strategies at best, and at worst, premature cessation of piano lessons due to feelings of inadequacy. While piano teachers might empathise and have strategies to address musical challenges, they may not be equipped to address the mindset challenges that can hinder adult students' ability to progress at the piano (Bowles, 2010).

Research illustrates that effective learning occurs when students are oriented towards mastery rather than performance, with a focus on the processes involved in learning as opposed to being focused on the end goal (e.g. Biggs \& Tang, 2011; Dweck, 2000; Dweck \& Master, 2012). This study investigates how a piano teacher 
might engage adult piano students in effective learning in such a way that mitigates frustrations and encourages engagement and longevity at the piano. In this paper I first discuss self-direction as an embodiment of effective learning before discussing experiential learning and how transformative pedagogical strategies relate to fostering self-direction. These inform the strategies utilised in the practitioner-based study that follows.

\section{Self-direction and the adult piano student}

Self-direction is often cited as a key requirement for adult students' musical learning (see Chen, 1996; Dabback, 2003; Mizok-Taylor, 2008; Wristen, 2006). Research finds, however, that adults tend to revert back to the dependence of their school days in piano lessons (Belzer, 2004; A. Taylor \& Hallam, 2008) and teachers often do not provide opportunities for self-direction to occur (Chen, 1996). While it has been posited that it is the role of the teacher to facilitate self-direction (Dabback, 2003; Mizok-Taylor, 2008; Wristen, 2006), the term itself often lacks formal definition within piano pedagogy. This is problematic if a teacher is to understand what this facilitation might entail.

Self-direction within piano pedagogy has often been linked with self-learning, freedom, independence and a lack of guidance (Swenson, 2006; A. Taylor \& Hallam, 2008; Wristen, 2006), and learning without a formal teacher (A. Taylor, 2011). These descriptions, however, absolve the teacher from a role in cultivating or facilitating self-direction. Despite this apparent synonymity with autonomy, Wristen (2006) and Dabback (2003) argue that self-direction does not mean an absence of guidance, but rather more responsibility and accountability being placed with the student. They also call for teachers to balance the implied freedom associated with self-direction with structure and support. Knowles, Holton, \& Swanson (2005) argue that while students take the initiative in their learning, this does not mean that guidance is absent. Within the field of adult learning, they describe self-direction as a process that involves several skills, including diagnosing learning needs; formulating learning goals; identifying resources for learning; choosing and implementing appropriate learning strategies; and evaluating learning. Thus, the role of the teacher is to enable the student to own the process, while supporting them to develop the required skills associated with self-direction.

How self-direction unfolds in practice is visually represented by David Kolb's (1984) experiential learning cycle (see figure 1), which 'matches general advice [instrumental music] teachers give about the need to plan, execute, and evaluate one's practice' (Jørgensen, 2004, p. 86) and is a meaningful framework for fostering selfdirection (Kreber, 2001). It also aligns with one of the main premises of adult learning; that learning needs to be experiential in nature. The main tenet is that it is not experience that leads to learning, but rather reflection on experience (Jarvis, 2010; Knowles, Holton \& Swanson, 2011; Mezirow, 2003). 


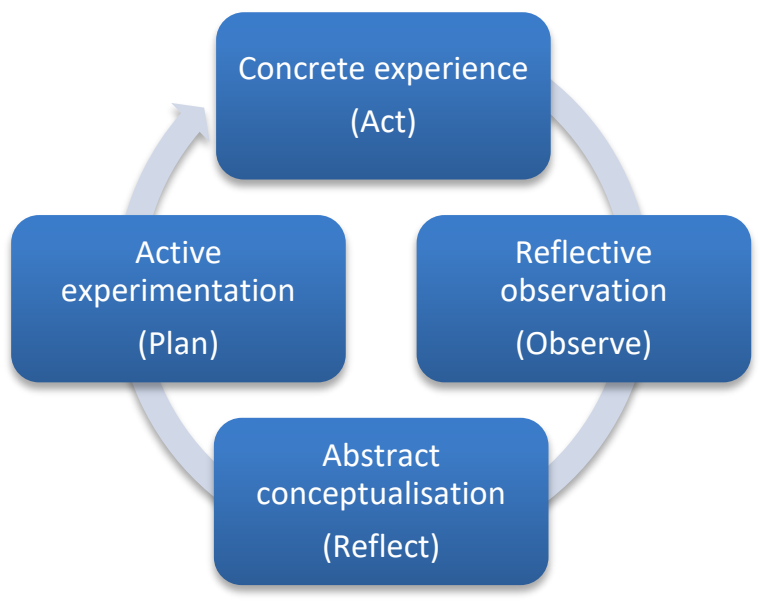

Figure 1: Kolb's (1984) experiential learning cycle

Within this cycle, the learner goes through four stages. In the concrete experience stage, the learner encounters a new experience or situation. This is followed by reflective observation, where the experience is reviewed and reflected upon from multiple perspectives. This is especially important if experiences are inconsistent with expectations or understanding (McLeod, 2013), as is often the case with adult students. In the abstract conceptualisation stage, the learner draws conclusions or modifies prior perspectives, making meaning from their experience. Finally, in the active experimentation stage, learners plan and implement new actions based on what has been learned. This leads to the next iteration of the cycle.

While this model has been promoted widely for adult educators, Wilson and Hayes (2002) caution that it has become ubiquitous and limiting 'because it restricts the way we see and understand experience' (p. 174). This may be due to the fact that it does not account for the internal motivational processes involved in effective reflective learning and self-direction, such as mindsets (Dweck, 2000) and selfefficacy (Lehman, Sloboda \& Woody, 2007; Schunk, 2012). Self-direction is arguably a deep approach to learning, requiring students to be inquisitive, probing and oriented towards process and mastery rather than end products and outcomes (Dweck, 2000; Zimmerman \& Schunk, 2012). It is these internal parameters that impact students' ability and willingness to engage (Merriam et al., 2007). Facilitating the growth of self-direction in adult students is thus dependent on the teacher cultivating both the 'will' and 'skill' (Maehr et al., 2002) of students to act in a selfdirected manner. Fostering student engagement in this way is a central aim of transformative pedagogy (Carey et al., 2013).

\section{Transformative pedagogy}

Traditional modes of one-to-one studio teaching are characterised by the transmission of knowledge and skills from the teacher to the student. Students' predominant learning thus occurs through imitation (Burwell, 2005) and instruction that limits flexibility, with the aim of achieving 'defined excellence' (Carey et al., 2013, p. 362). This approach to learning and teaching does little to focus on the internal processes of 
the students or to allow them to take ownership or lead their learning, making it unsuitable for fostering self-direction in students.

In contrast to this, transformative pedagogy (Carey et al., 2013) focuses on students coming to understand learning processes and developing their reflective capabilities. As Carey et al (2013) explain, it "is characterised by a "deep" approach to learning orientation on behalf of the teacher, and pedagogical agility in terms of its collaborative, explorative, scaffolded, meaningful, and contextualising qualities' ( $p$. 361), changing how learning is structured and understood (Biggs \& Tang, 2011). Its focus is on supporting student autonomy and placing prime importance on meaning making through reflection, which are also integral to self-direction.

Strategies involved in a transformative pedagogical approach to learning and teaching include creating a 'culture of inquiry' (Snyder \& Snyder, 2008) and promoting metacognitive thinking (Bathgate et al., 2012; Mezirow, 2000) through the use of meaningful dialogue and questioning of students, and encouraging experiential learning and reflective practice (Jarvis, 2010). Learners are also involved in planning the structure and direction of their learning in order to increase autonomy and ownership (McPherson \& Zimmerman, 2002; A. Taylor \& Hallam, 2008). This increases the relevance of learning for students and thus their desire to engage (Jarvis, 2010; Knowles et al, 2011). Transformative pedagogy also involves acknowledging students' experiences and emotions while helping them to transform any problematic perspectives that might be inhibiting their learning (Mezirow, 2003; E. W. Taylor, 2008).

Taking a transformative approach to lessons has been known to increase student autonomy and engagement with learning in tertiary one-to-one instrumental music settings (Carey et al., 2018) and to also increase adult novice piano students' engagement with repertoire learned (Coutts, 2018). In this study I explore its potential to engage adult students with their learning within the context of their piano lessons, in order to promote greater self-direction and ownership of learning. The structure of this study is offered below.

\section{Teacher self-reflection as research design}

This study is part of a larger nine-month project that sought to understand how to engage adult piano students with all aspects of their learning, including repertoire learned, lesson interactions and home practice (Coutts, 2016). Recognising that translation of learning theory into action is a highly subjective process (Cleaver \& Ballantyne, 2014), I used a practitioner-based methodology that allowed me to implement, adapt and reflect on the use of transformative pedagogical strategies within the context of my own piano studio. As Loughran and Berry (2005) argue, 'the ability to be explicit about what one is doing and why is enhanced through systematically inquiring into learning through experience (self-study) so that the relationship between knowing and doing might be more accessible' (p. 194). Rather than being a recipient and consumer of research and practice, the teacher is seen as 'the one who mediates ideas, and constructs meaning and knowledge and acts upon 
them' (Richardson, 1994, p. 6). This allows the teacher-researcher to move between know-how, know-that and know-what, through 'intellectual diagnostic rigour in the critical reflection on practice' (Nelson, 2013, p. 60).

While the isolated context of this research makes overarching generalisability difficult, it is understood by the educational community that much can be learned from the unique experiences of individuals (Ellis \& Bochner, 2000; Flyvbjerg 2006; L. Richardson, 2003), and that the practical wisdom of teachers plays an important role in informing pedagogical strategies of others (Gelder, 2005, p. 41). As such, the experiences and consequent insights shared in this study may be useful for other studio music teachers to reflect on in relation to their own teaching context.

\section{Data generation and analysis}

Following the ethics protocols of the host institution, the project at large involved six of my adult students who were representative of student demographics within my piano studio. Data was generated through student interviews, home practice journals and a teacher journal assisted by video recording lessons. The data drawn upon for this current publication was my teaching journal, in which I planned and reflected on my teaching choices in piano lessons with the six students involved on a weekly basis.

Taking a practitioner-based methodology lent itself to the use of the experiential learning cycle (Kolb, 1984), not only as a model of engaged learning for students, but also as a practical approach to reflecting on and planning my own actions. This meant that the journal was as much a pedagogical tool as it was a data generation method, designed to facilitate the evolution of my teaching. My teaching journal housed my self-reflections, observations and perspectives on the lessons after the event, and my interpretations, forward planning and preliminary analyses of the outcomes of strategies used and was also informed by my interpretations of the literature on adult learning and student engagement. It also served to highlight my expectations, agendas, frames of reference and habitual teaching choices in order to question the assumptions and underlying reasons behind them, and to understand how they potentially influence the learning environment (Mezirow, 2003).

The use of video was especially helpful through the journaling process, and is a recommended tool for self-reflection (Derry, 2007; Hollingsworth, 2005; Tripp \& Rich, 2012), which is arguably more effective than journaling alone (McAllister, 2008), lending a level of reliability to the study and the analysis process, as it could be revisited to check for representations, multiple perspectives and other ways to interpret the lesson interactions throughout the analysis and writing phases (Hollingsworth, 2005).

I took a thematic approach to analysis, which complemented my research aims and study design as it allowed analysis to start from a template of broad themes based on the purpose of the study (Fereday \& Muir-Cochrane, 2006). While there are many factors that might influence students' actions and levels of engagement within lessons 
that are outside of the teacher's sphere of influence (such as external circumstances, stress levels, tiredness and other pressures and priorities), the study lasted nine months, allowing for certain trends to be identified between my actions and communication choices as a teacher and student responses and levels of engagement and interaction.

In the following section I describe the new insights I gained throughout this study, along with the resultant changes in my teaching strategies and students' behaviours. Unexpectedly, much of the catalyst for change as a teacher was due to reflecting on lessons with one of my participants, Cathryn, who exhibited much of the deep learning skills I was aiming to develop in other students. As such, part of the discussion following discussion is framed as a case study of our lessons together before applying those insights more broadly within my teaching. The discussions that follow focus on the changes in my teaching as I explored the implementation of transformative pedagogical strategies.

\section{Lesson structure: From teacher-led to student-centred}

Prior to this study, if I had been asked to describe my teaching style, I would have said that it was student-centred, as I felt as though I focused on the needs of each individual student. Much like Siebenaler (1997), I thought an effective lesson pattern was one in which the teacher modelled how to simplify challenges and had the student repeat sub-skills for mastery before putting them into the context of the piece. I built on prior knowledge through scaffolding and moved away from the score for technical development and conceptual understanding. I also treated lessons like a shared practice session, breaking down challenges into manageable chunks, isolating passages where required, verbalising rhythms and coordination with students and encouraging slow and deliberate playing. Unpacking common interactions in lessons was revealing, however, as I came to realise that my teaching was actually teacherled, rather than student-centred, focusing on what I believed was best for the student at any given moment instead of their perceived needs. The figure below superimposes a typical lesson interaction prior to this study onto the experiential learning model:

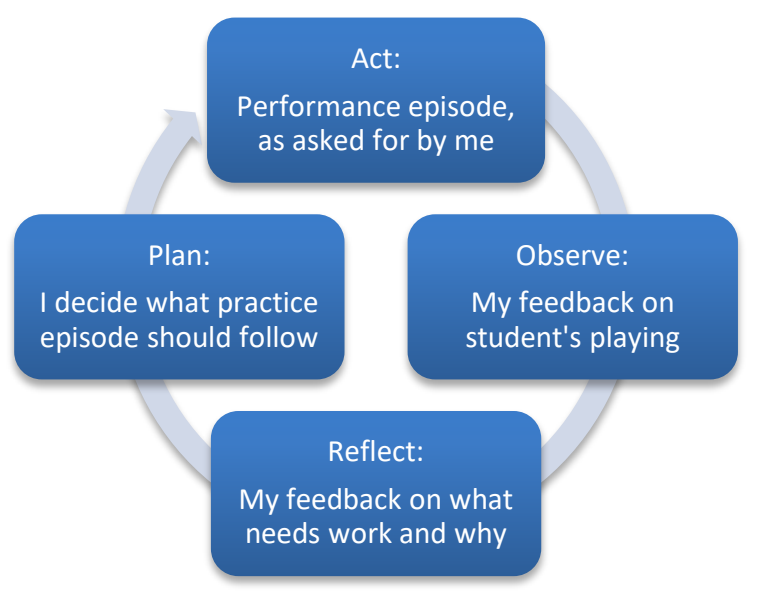

Figure 2: Example 1 of teacher control of the experiential learning process. 
Maintaining control of students' learning was the exact opposite of my intentions. Nevertheless, this type of interaction was common early in the study. The lesson would start with a performance episode, a run-through of a piece without an expressed purpose, focus, or intention. The implicit purpose was to expose areas that required work. I would follow up with feedback and explanations as to what went well and what needed more attention and why. The next event would have an explicit purpose - to put my suggestions into action - making it a practice episode rather than a performance episode.

Requesting students to play for me in this way was often met with nervousness, as evidenced through students' reluctance to play, shaking hands or fingers, or precursory excuses as to why they did not achieve as much as they had hoped through the week. It appears that for adult novices, taking a teacher-led pedagogical approach resulted in, or at least reinforced, potential fear of inadequacy and low selfconfidence (McPherson \& Zimmerman, 2002), and perceptions of low ability, which can be personally devastating for students (Zimmerman \& Schunk, 2012). Such feelings of helplessness can adversely impact learning as focus is on self-protection rather than engaging with tasks at hand (Dweck, 2000). This was evident in common cries from students, which included, 'But I could do it at home', 'I can play it better than that', or 'Your piano is so different to mine!'

Reflecting on these interactions, I can see how playing for me followed by praise or constructive criticism might create or reinforce a perspective that my role as a teacher was to judge. If playing for me encouraged a focus on the end product rather than the learning process and created a feeling of being judged, I wondered why I insisted on starting lessons this way. Firstly, I thought that improvements exhibited through playing were indicative of learning; secondly, it would highlight areas that needed attention during the lesson.

While I came to realise that performance episodes disempowered students, unless the expressed goal was to perform a piece that was at a comfortable level of familiarity, I still believed that playing ability in lessons exhibited signs of learning and growth: If you want to learn to play the piano, then surely how well you play demonstrates how much you have learned? (teaching journal, week 18). I did, however, want to eliminate the stress associated with expectations to perform. I started to ask students how much of a piece they would like to start with. This gave them a chance to choose to play parts they knew well, or to work up to a trouble spot and stop so that we could do isolated work on it together. Students appeared to receive this option gratefully, with the reprieve from struggling through parts that were not yet performance-ready visibly evident in their demeanour. This was just the first step in passing ownership of learning to students. Analysing lessons with a student who already engaged critically and deeply with her learning and took the lead in lessons - the exact goal I had for my other adult students - proved to be an effective means of understanding how I might foster this approach further with others. 


\section{Case study: Learning from Cathryn}

One of my intermediate students, Cathryn (see note 1), approached lessons methodically with an inquisitive attitude and a desire to address challenges of technique and musical expression. Her thirst for conceptual understanding as well as procedural execution meant our lessons together were exploratory and rich in discussions, effortlessly taking on the 'culture of inquiry' (Snyder \& Snyder, 2008) environment that I sought with all students. I recognised this three months into the study and so decided to analyse our lessons together to see what I could transfer to my other students. Viewing the common interactions surrounding practice episodes with Cathryn highlights how this unfolded in our one-on-one piano lessons together:

1. Cathryn reflects on her week's practice and/or asks questions

2. I respond and we discuss

3. I ask her to play something relevant to her reflections/questions

4. Practice episode

5. Questions for feedback - both of us asking and answering questions and offering our thoughts freely

6. Teacher modelling with Cathryn copying and reflecting and/or asking questions on techniques, strategies and musical output

From here, the rest of our time on a piece would cycle through steps 2 to 5 above. When we changed focus to another piece, I asked what she would like to focus on next, and the steps began at number one again.

In relation to the experiential learning cycle, Cathryn's lessons began with stage two: observe what happened. These reflections extended beyond practice episodes in lessons to the week's home practice. For other students, while I had endeavoured to give them ownership of lesson structure, thus far it had started with stage four: planning - now what? The difference between the two is that Cathryn's first episode at the piano was a practice episode and the others were still performance episodes. I came to realise that Kolb's experiential learning cycle does not need to start with an immediate experience within the lesson, but can span a range of time frames that include experiences in home practice.

In the following months I endeavoured to elicit more reflections from other students from the beginning of their lessons. I adapted questions to go beyond merely asking, 'What would you like to start with?' to include those relating to challenges and reflections on the week. Types of questions this included are:

- Were there any trouble spots this week?

- What were you aiming for with this piece?

- How did you go with [specific point of focus]?

- How did you approach this section? 
- Do you just want to play, or would you like to break it up?

- Were there any questions from your practice this week?

The main difference this approach creates is that an explicit intention comes from the student before playing commences. It also allows students to express difficulties and ask questions prior to playing, removing the perception that they need to 'perform and be judged'. Further, practice episodes and activities explored were also then relevant to the student's expressed needs. From my experiences in the study and beyond, it became evident that starting with students' reflections and insights from the week was much more conducive to actively engaging them in lessons than starting with playing.

Once the focus of a segment of a lesson is chosen, it is important to continue to empower students to be metacognitively involved in order for them to engage in deliberate practice during home practice (Mayer, 2004). I achieved this through changes in how I used modelling and questioning as teaching strategies. These are explored in turn below.

\section{Effective modelling for student engagement}

Modelling, where I demonstrated and explained actions at the piano before asking the student to imitate, was a regular occurrence in lessons. Early in my teaching I chose this strategy to demonstrate the desired output for students to try to replicate when performance episodes highlighted challenges of coordination, expression or technique (Speer, 1994). As students cooperated and were behaviourally involved, I took for granted that we were interacting collaboratively. Once again, however, I maintained control of the student's learning, as illustrated in the figure below.

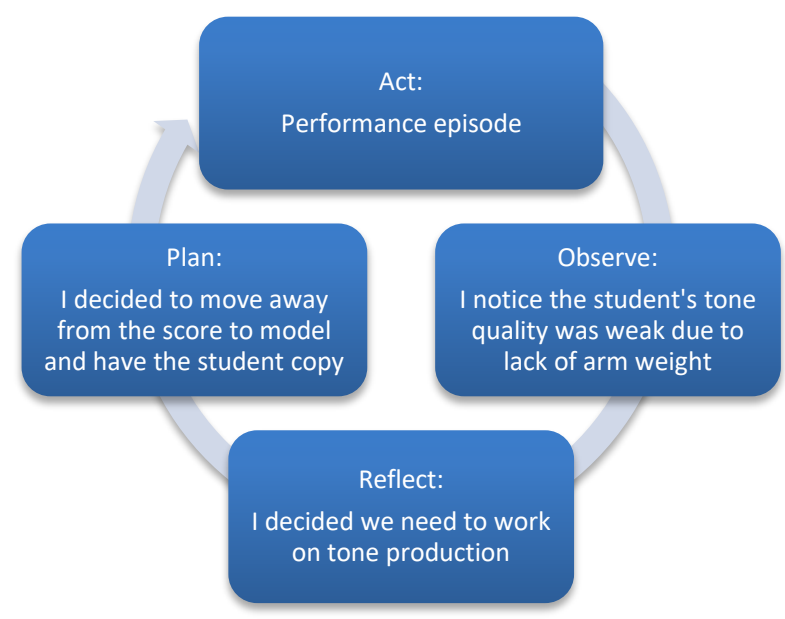

Figure 3: Example 2 of teacher control of the experiential learning process.

One of the issues with this approach is that it does not require great amounts of cognitive or metacognitive engagement. Thus, it is not conducive to developing the skills of self-direction that could be utilised during home practice. There are other ways to use modelling however. It can be a form of 'cognitive apprenticeship' (Ley \& Young, 2001) if it includes strategy evaluations (McPherson \& Zimmerman, 2002) 
and modelling of thought processes used in problem solving (Elder \& Paul, 2010). I reflected on this in my journal half way through the study:

I've realised that modelling needs to be sandwiched between student reflections or questions so the student guides me on when modelling is helpful. If my modelling fits their expressed needs, it seems to be more effective for retention of learning and they are more able to transfer learned experiences to other musical contexts.

This means that when modelling and explanations follow a student's question or comments, the student has already expressed an intention to understand. Therefore, engagement does not need to be created or instigated by me. With the desire to know implicit in the student, discussions, demonstrations and attempts to replicate my actions were more meaningful and relevant to the student, resulting in active engagement with the tasks.

\section{Developing inherent student feedback through questioning}

A main premise of experiential learning is that it is not experience that leads to learning, but reflection on experience (Akella, 2010; Kolb, 1984). Much of the feedback within lessons, however, often comes from the teacher. It has been suggested that adult piano students like frequent and honest teacher feedback (Wristen, 2006) and frequent teacher praise (Cooper, 2001), with the effectiveness of such comments being dependent on specificity, contingency, credibility and variety (Siebenaler, 1997). Compared to the aims of this study, however, this might be interpreted as preserving a reliance on the teacher. Rather than choose to take ownership of feedback, I chose to use questioning to encourage students to reflect for themselves. These fell into four categories:

- Guided discovery: Asking questions to draw students' awareness to specific stimulus to facilitate discovery and learn new concepts and skills

- Guided feedback: Asking questions so that feedback can come from the students, rather than being given by the teacher

- Guided problem solving: Modelling and asking questions around the problemsolving process

- Encouraging reflective observations by asking critical questions before and after playing, directing students' focus to relevant musical concepts and actions

When I first started asking students questions with regards to strategy choice, such as, 'How would you approach this?' or 'What strategy will you use?' students' answers were general or vague, such as, 'I'll just repeat it over and over', 'I'll practise it more', 'With great difficulty', or simply, 'I don't know.' Viewing responses and corresponding body language in the lesson videos, I sensed that this sometimes reflected a lack of confidence or avoidance of using strategies and investing the intense amount of focus required, and at other times, genuine confusion. These students had been learning piano with me for nearly two years at this point, so I 
thought that asking their thoughts around useful practice strategies pertaining to their challenges would elicit straightforward responses based on our previous interactions in similar contexts. I was fascinated, and at the time admittedly a little surprised and deflated, by how little some would be able to engage in answering questions to this effect. Again, this seems to indicate that teacher-centred lessons may not equate to long-term and effective learning.

The inability for most students to answer questions pertaining to strategy choice illustrates that while they could follow directions and answer questions relating to content when prompted, they were unaware of the processes behind the questions I asked. Rather than explaining, as I previously would, I asked questions to prompt for more detail, such as 'Repeat it how?' or encouraged them to draw on past experiences to help to interpret the needs of the current context. These questions would sometimes result in deeper insights, or would result in me modelling the decision-making and problem-solving process by asking and answering the questions myself (Elder \& Paul, 2010).

Over time, as students' familiarity with new lines of questions increased, so too did their engagement in discussions. As with modelling, this was especially the case when questions aligned with student interests. In one instance, while I was busy asking questions about how I was executing a certain passage at the piano, the student interjected, noticing a solution to a different challenge he was having. This illustrates that a student's attention focuses on what they deem relevant, rather than what the teacher believes is relevant. We focused on his perceived challenge first, and then applied the solution within the context of the coordination challenge I had observed. This example of me being led by a student's perceived needs rather than my own reminded me that how my students and I interpret challenges are not necessarily congruent. It also illustrates that creating an environment where students feel safe to share their thoughts and difficulties and to have the teacher be led by those can increase engagement for students. In the case of this example, once the student's needs had been met, he was happy to focus elsewhere as required.

In the latter half of the study, as students were also becoming accustomed to owning the lesson structure and directing me to their perceived needs, students began to describe their thoughts and offer potential approaches before any questions were asked. There was also an increase in students asking more questions of their own, indicating that engagement and a desire for deeper understanding was increasing. This increase also corresponded with a shift in my focus, from lesson content to a desire to understand students' experiences, perspectives and feelings in relation to their musical journey.

\section{Acknowledging Students' Experiences and Emotions}

Acknowledging the need to begin with their experiences during home practice, I also realised that I needed to give students a safe space to share those experiences, voice their expectations - whether unrealistic or not - and to vent their frustrations and challenges. Towards the end of the study, I started instigating more discussions with 
students around their learning experiences. This had started to occur earlier in isolation, but now I spent time at the beginning of the lesson to simply ask students how their weeks had gone, and to actually listen and encourage them to share their experiences. Previously, my perfunctory, 'How's your week been?' really did not need any more reply than, 'good thanks'.

I learned to listen authentically and to not interject with my opinions of their experiences. My old comments tended to inadvertently undermine the feelings of the student in a rush to get to the musical focus of the lesson. If students came in saying 'I should be able to play this', I would say, 'No you shouldn't, you're still learning', 'It's only been a week [or two]', or even comments in jest, such as 'If you could already play, I'd be out of a job'. Now I acknowledge their challenges and ask different questions, such as 'That must be frustrating... is there anything specific that affected your practice?', 'What can we focus on to help?' I would remind them of their progress and ask them to also share any positive thoughts from their week. If they struggled to find any, again, I would ask why, and if there is something we could do in lessons to help solve their challenges at home.

Initially I saw this as a poor use of lesson time. I felt the purpose of a lesson is to focus on the music and the strategies needed to progress. What I learned, however, was that by allowing them the space and freedom to talk, students were more willing to set aside their self-judgements and to engage at the piano. Cathryn once explained that by getting everything out in the open, she was managing my expectations of her. This was a powerful statement, and I realised that this is what other students needed to do too. I noticed a remarkable difference in those who at times had struggled to engage in lessons. For example, after giving Graham, a student who struggled with expectations of 'talent' and 'ease', the space to acknowledge his self-judgements and criticisms of himself, it appeared he then felt safe to set that aside and commit to the activities in the lessons. Without this, he would deflect, avoid and be unable (or unwilling) to engage in activities throughout his lessons. Nervous behaviour also drastically decreased in lessons in the final couple of months of the study, especially for Anne, who seemed to suffer the worst with anxiety in lessons, visibly shaking and stumbling as she played. When I asked her what had changed this, she responded, 'I think we're focusing on the music more rather than me playing for you. I think that's important' (lesson interaction, week 33).

This space also led to opportunities to discuss frames of reference, prior experiences, expectations and alternative perspectives on how to view their challenges, and gave me insight into the experiences that had shaped their views. Through this, our rapport grew substantially, and I got to know my students on a much deeper level than I previously had. I learned that lesson time was students' time to use as they needed. It appeared that for most, this first was to explain their week's emotions and improvements, or perceived lack of improvements, depending on the week's practice. Then, I asked them what specific musical challenges we could explore together in lessons, or where they thought it was best to start, before approaching tasks from a problem-solving perspective rather than a performance 
perspective, led by the students.

\section{Learning outcomes and recommendations}

Through this study I learned that an optimal lesson environment that fosters and encourages self-direction is collaborative and full of discussions. This was made possible through the significant change in the structure of lessons. By acknowledging and exploring students' perspectives towards their progress, and their challenges and frustrations at the start of their lessons, students were more able to set their negative emotions aside and engage in learning activities in their lessons. This also set the climate for the lesson to be non-judgemental and exploratory, full of discussions and effective questioning that facilitated students to take ownership of their learning. In this way, lessons fostered the 'culture of inquiry' that placed students' experiences and perceived challenges at the heart of the lesson. In relation to the experiential learning cycle, lessons took the following structure:

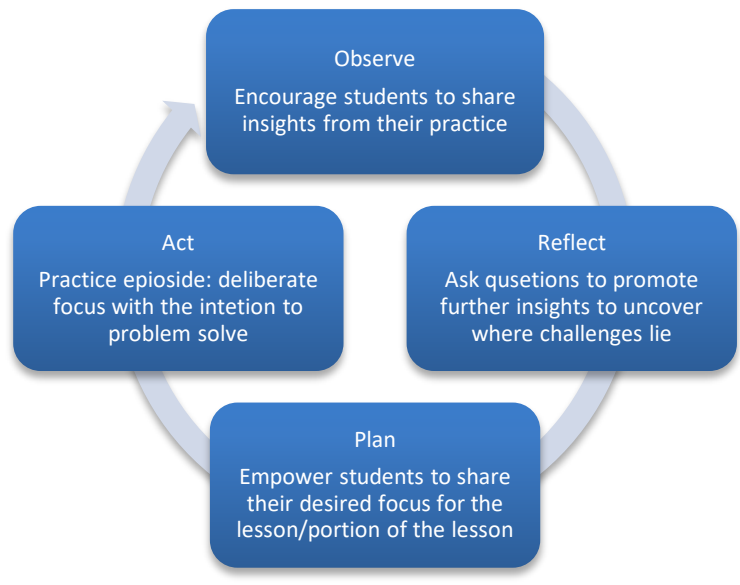

Figure 4: Lesson structure that empowers and supports students to take ownership of their learning

This change in lesson structure increased my pedagogical agility (Carey et al., 2013) as I became flexible in my teaching approach and I felt comfortable allowing students to control the shape of the lesson.

This could only occur through setting intentions for my pedagogical approach to lessons, reflecting on my teaching practice and noticing and addressing discrepancies between my intentions and actions. Once I started to critically reflect on my teaching, I realised that my initial approach to lessons was at odds with my pedagogical intention of putting the student at the centre of lessons. While an uncomfortable realisation, this was the catalyst for change. I started to value students' input more and learned to listen as much as I spoke. Allowing students space to talk created a safe and supportive environment, deepened rapport with students and removed the performative expectations that used to be associated with lessons. It also helped to foster the collaborative and reciprocal approach to lessons that is advocated for in transformative pedagogy (Carey et al., 2013), whereby interdependence and connectivity is key (Merriam et al., 2012). 
I arrived at two main realisations through this study. The first is that adult students' behaviours, in relation to their engagement at the piano, can be directly affected by our behaviours and choices as teachers. This is both empowering and burdening, as with this realisation is the responsibility to stay mindful and deliberate in our choices, to not react to circumstances, but to be aware of how we want to react, and then instead to ask questions and discover what each students needs from us at any one time. In doing so, we can help our adult students to engage positively with their learning. This is, however, more readily achieved with some students more than others, depending on their expectations for their learning. While it was not within the scope of this article to investigate the mindsets, perceptions and characteristics of each student participant, further publications on this research project will explore individual students' experiences throughout the study and will more closely examine the student-learning and student-teacher relationships in relation to mindsets and student engagement. While individual characteristics of students do influence how lessons unfold - as would the individual characteristics of the teacher - the teaching strategies explored within this article were applicable and adoptable within each student participants' lessons. This did, however, depend on my ability to become aware of my own perceptions and expectations.

The second realisation is thus that unless we consciously and critically reflect on our teaching practices, our intentions and actions may not be aligned. While selfreflection can be uncomfortable, I recommend that teachers continue to reflect on their own actions and to critically question their impact - adverse or positive - on the learning environment, and to seek to find ways to interact that empower students to engage constructively with their learning. Through this, transformation of the teacher, the student, and the learning environment is possible.

Despite the deeply contextual nature of this study and my teaching practice, the applicability of the strategies throughout this article to other teachers' practices should not be discounted. The usefulness of my pedagogical approach warrants further exploration to ascertain whether or not the strategies used here unfold in a similar manner in different teaching studios. It is also important, however, to acknowledge that this is just one approach to transformative pedagogy, and one that evolved over the nine months of the study. There are likely many ways that transformative pedagogy could unfold within a one-to-one piano lesson.

Transformative pedagogy is not simply about implementing strategies; it involves a new perspective towards students, the role of the teacher, and expectations for students' learning. I have transformed as a teacher as a result of my experiences throughout this study and beyond. I have a deeper empathy and understanding, not just of my students, but also of myself. Students are having breakthroughs in their own time, leading me more than the other way around, and offering deeper reflective insights all the time. It is a process that does not have an end point for them or me, just like learning to play the instrument.

\section{Acknowledgements}


A heartfelt thank you goes to the students who participated in this study and shared this learning journey with me.

\section{Funding statement}

The author received no financial support for the research, authorship, and/or publication of this article.

\section{Notes}

1. Pseudonyms have been used to protect student identities throughout, consistent with pseudonyms used in the publication on the repertoire selection portion of the study (Coutts, 2018).

\section{References}

Akella, D. (2010). Learning together: Kolb's experiential theory and its application. Journal of Management and Organization, 16(1), 100-112. doi:10.5172/jmo.16.1.100

Bathgate, M., Sims-Knight, J. \& Schunn, C. (2012). Thoughts on thinking: Engaging novice music students in metacognition. Applied Cognitive Psychology, 26(3), 403-409. doi:10.1002/acp.1842

Biggs, J. B. \& Tang, C. (2011). Teaching for quality learning at university ( $4^{\text {th }} \mathrm{ed}$.). New York, NY: Society for Research into Higher Education and Open University Press, McGraw Hill.

Bowles, C. L. (2010). Special topics-Teachers of adult music learners: An assessment of characteristics and instructional practices, preparation, and needs. Update: Applications of Research in Music Education, 28(2), 50-59. doi:10.1177/8755123310361762

Burwell, K. (2005). A degree of independence: Teachers' approaches to instrumental tuition in a university college. British Journal of Music Education, 22(3), 199-215. doi: 10.1017/S0265051705006601

Carey, G. M., Bridgstock, R., Taylor, P., McWilliam, E. \& Grant, C. (2013). Characterising one-to-one conservatoire teaching: Some implications of a quantitative analysis. Music Education Research, 15(3), 357-368. doi:10.1080/14613808.2013.824954

Carey, G., Coutts, L., Grant, C., Harrison, S., \& Dwyer, R. (2018). Developing a shared understanding of optimal learning and teaching in the tertiary music studio. Music Education Research. https://doi.org/10.1080/14613808.2017.1409204

Chen, H. (1996). An investigation of self-directed learning among non-music major adult piano learners in one-to-one piano instruction (Doctoral dissertation). Retrieved from ProQuest Dissertations \& Theses database. (UMI No. 9635962).

Cleaver, D. \& Ballantyne, J. (2014). Teachers' views of constructivist theory: A 
qualitative study illuminating relationships between epistemological understanding and music teaching practice. International Journal of Music Education, 32(2), 228-241. doi:10.1177/0255761413508066

Cooper, T. L. (2001). Adults' perceptions of piano study: Achievements and experiences. Journal of Research in Music Education, 49(2), 156-168. doi: $10.2307 / 3345867$

Coutts, L. (2018). Selecting motivating repertoire for adult piano students: A transformative pedagogical approach. British Journal of Music Education. https://doi.org/10.1017/S0265051718000074

Coutts, L. (2016). Engaging Adult Piano Students Through Transformative Pedagogical Approaches. (Doctoral thesis). Queensland Conservatorium Griffith University, Brisbane Australia.

Dabback, W. M. (2003). Toward andragogy in music: Examining the gap between theory and emerging practice in the instrumental music education of older adults. International Journal of Community Music, 2(1), 1-16. Retrieved from http://www.intellectbooks.co.uk/MediaManager/Archive/IJCM/Volume\%20B /03\%20Dabback.pdf

Derry, S. J. (2007). Guidelines for video research in education: Video research in education. Chicago, IL: NORC at the University of Chicago.

Dweck, C. S. (2000). Self-theories: Their role in motivation, personality, and development. New York, NY: Taylor \& Francis Group.

Dweck, C. S. \& Master, A. (2012). Self-theories motivate self-regulated learning. In B. J. Zimmerman \& D. H. Schunk (Eds.), Motivation and self-regulated learning: Theory, research, and applications (pp. 31-52). New York, NY: Lawrence Erlbaum Associates.

Elder, L. \& Paul, R. (2010). The art of asking essential questions $\left(5^{\text {th }}\right.$ ed.). Tomales, CA: Foundation for Critical Thinking.

Ellis, C. \& Bochner, A. P. (2000). Autoethnography, personal narrative, reflexivity. In N. K. Denzin \& Y. S. Lincoln (Eds.), Handbook of qualitative research (2nd ed., pp. 733-768). Thousand Oaks, CA: SAGE.

Fereday, J. \& Muir-Cochrane, E. (2006). Demonstrating rigor using thematic analysis: A hybrid approach of inductive and deductive coding and theme development. International Journal of Qualitative Methods, 5(1), 80-92. doi: $10.1177 / 160940690600500107$

Flyvbjerg, B. (2006). Five misunderstandings about case-study research. Qualitative Inquiry, 12(2), 219-245. doi:10.1177/1077800405284363

Gelder, T. V. (2005). Teaching critical thinking: Some lessons from cognitive science. College Teaching, 53(1), 41-46. doi:10.2307/27559216

Hollingsworth, H. (2005). Learning about teaching and teaching about learning: Using video data for research and professional development. Paper presented at Using Data to Support Learning: $10^{\text {th }}$ Conference of the Australian Council for Educational Research (ACER), Melbourne, Australia. Retrieved from http://research.acer.edu.au/cgi/viewcontent.cgi?article=1015\&context=researc $\underline{\mathrm{h} \text { conference } 2005}$ 
Jarvis, P. (2010). Adult education and lifelong learning: Theory and practice (4th ed.). London, UK: Routledge.

Jørgensen, H. (2004). Strategies for individual practice. In A. Williamson (Ed.), Musical excellence: Strategies and techniques to enhance performance (pp. 85-104). Oxford, UK: Oxford University Press.

Knowles, M. S., Holton, E. F., III \& Swanson, R. A. (2011). The adult learner: The definitive classic in adult education and human resource development (7th ed.). London, UK: Elsevier.

Kolb, D. (1984). Experiential learning: Experience as the source of learning and development. Engelwood Cliffs, NJ: Prentice Hall.

Kreber, C. (2001). Leaning experientially through case studies? A conceptual analysis. Teaching in Higher Education, 6(2), 217-228. doi:10.1080/13562510120045203

Lehmann, A. C., Sloboda, J. A. \& Woody, R. H. (2007). Psychology for musicians: Understanding and acquiring the skills. Oxford, UK: Oxford University Press.

Ley, K. \& Young, D. B. (2001). Instructional principles for self-regulation. Educational Technology Research and Development, 49(2), 93-103. doi:10.1007/bf02504930.

Loughran, J. \& Berry, A. (2005). Modelling by teacher educators. Teaching and Teacher Education, 21(2), 193-203. doi:10.1016/j.tate.2004.12.005

Maehr, M. L., Pintrich, P. R. \& Linnenbrink, E. A. (2002). Motivation and achievement. In R. Colwell \& C. P. Richardson (Eds.), The new handbook of research on music teaching and learning (pp. 348-372). New York, NY: Oxford University Press.

Maris, B. E. (2000). Making music at the piano: Learning strategies for adult students. Oxford, UK: Oxford University Press.

Mayer, R. E. (2004). Should there be a three-strikes rule against pure discovery learning?: The case for guided methods of instruction. American Psychologist, 59(1), 14-19. doi:10.1037/0003-066X.59.1.14

McAllister, L. S. (2008). Evaluating teaching effectiveness in music. The American Music Teacher, 58(3), 14-17. Retrieved from http://drora.me/wpcontent/uploads/2014/04/evaluating-teaching-effectiveness-in-music.pdf

McLeod, S. A. (2013). Kolb: Learning styles. Retrieved from www.simplypsychology.org/learning-kolb.html

McPherson, G. E. \& Zimmerman, B. J. (2002). Self-regulation of musical learning. In R. Colwell \& C Richardson (Eds.), The new handbook of research on music teaching and learning: A project of the Music Educators National Conference (pp. 327-347). Oxford, UK: Oxford University Press.

Merriam, S. B., Caffarella, R. S. \& Baumgartner, L. M. (2012). Learning in adulthood: A comprehensive guide ( $3^{\text {rd }}$ ed.). San Francisco, CA: John Wiley \& Sons.

Mezirow, J. (2000). Learning to think like an adult. In J. Mezirow (Ed.), Learning as transformation: Critical perspectives on a theory in progress (pp. 3-33). San 
Francisco, CA: Jossey-Bass.

Mezirow, J. (2003). Transformative learning as discourse. Journal of Transformative Education, 1(1), 58-63. doi:10.1177/1541344603252172

Mizok-Taylor, R. J. (2008). Promoting self-directed learning in adult piano instruction (Doctoral dissertation). Retrieved from ProQuest Dissertations \& Theses database. (UMI No. 3376459).

Nelson, R. (2013). Conceptual frameworks for PaR and related pedagogy: From 'hard facts' to 'liquid knowing'. In R. Nelson (Ed.), Practice as research in the arts: Principles, protocols, pedagogies, resistances (pp. 48-70). New York, NY: Palgrave Macmillan.

Richardson, V. (1994). Conducting research on practice. Educational Researcher, 23(5), 5-10. doi:10.3102/0013189X023005005

Siebenaler, D. J. (1997). Analysis of teacher-student interactions in the piano lessons of adults and children. Journal of Research in Music Education, 45(1), 6-20. doi: $10.2307 / 3345462$

Snyder, L. G. \& Snyder, M. J. (2008). Teaching critical thinking and problem solving skills. Delta Pi Epsilon Journal, 50(2), 90-99. Retrieved from http://reforma.fen.uchile.cl/Papers/Teaching\%20Critical\%20Thinking\%20Skil ls $\% 20$ and $\% 20$ problem $\% 20$ solving $\% 20$ skills $\% 20$ \%20Gueldenzoph, \%20Snyder.pdf

Speer, D. R. (1994). An analysis of sequential patterns of instruction in piano lessons. Journal of Research in Music Education, 42(1), 14-26. doi:10.2307/3345333

Swenson, T. S. (2006). Profiles of career-aged keyboard students: Attitudes, preferences, and demographics (Doctoral dissertation). Retrieved from ProQuest database. (UMI No. 3211367)

Taylor, A. (2011). Older amateur keyboard players learning for self-fulfilment. Psychology of Music, 39(3), 345-363. doi:10.1177/0305735610376262

Taylor, A. \& Hallam, S. (2008). Understanding what it means for older students to learn basic musical skills on a keyboard instrument. Music Education Research, 10(2), 285-306. doi:10.1080/14613800802079148

Taylor, E. W. (2008). Transformative learning theory. New Directions for Adult and Continuing Education, 119, 5-15. doi:10.1002/ace.301

Tripp, T. \& Rich, P. (2012). Using video to analyze one's own teaching. British Journal of Educational Technology, 43(4), 678-704. doi:10.1111/j.14678535.2011.01234.x

Uszler, M. \& Upitis, R. (2000). The adult student. In M. Uszler, S. Gordon \& S. M. Smith (Eds.), The well-tempered keyboard teacher (pp. 55-78). Belmont, CA: Schirmer.

Wiezbicki-Stevens, K. (2009). Metacognition: Developing self-knowledge through guided reflection (Doctoral dissertation). Retrieved from http://scholarworks.umass.edu/open_access_dissertations/126/

Wilson, A. L. \& Hayes, E. R. (2002). From the editors: The problem of (learning infrom-to) experience. Adult Education Quarterly, 52(3), 173-175. doi:10.1177/0741713602052003001 
Wristen, B. (2006). Demographics and motivation of adult group piano students. Music Education Research, 8(3), 387-406. doi:10.1080/14613800600957503

Zimmerman, B. J. \& Schunk, D. H. (2012). Motivation: An essential dimension of self-regulated learning. In B. J. Zimmerman \& D. H. Schunk (Eds.), Motivation and self-regulated learning: Theory, research, and applications (pp. 1-30). New York, NY: Lawrence Erlbaum Associates. 